\title{
Short review on the origin and countermeasure of biomass slagging in grate furnace
}

\author{
Yiming Zhu, Yanqing Niu, Houzhang Tan* and Xuebin Wang \\ MOE Key Laboratory of Thermo-Fluid Science and Engineering, Xi'an Jiaotong University, Xi'an, China
}

Edited by:

S. K. Tyagi, Sardar Swaran Singh

National Institute of Renewable

Energy, India

Reviewed by:

István Barabás, Technical University of Cluj-Napoca, Romania

Umakanta Jena, Desert Research

Institute, USA

Sachin Kumar, Sardar Swaran Singh

National Institute of Renewable

Energy, India

*Correspondence:

Houzhang Tan, MOE Key Laboratory of Thermo-Fluid Science and

Engineering, Xi'an Jiaotong

University, No. 28, Xianning West

Road, Xi'an, Shaanxi 710049, China

e-mail:tanhz@mail.xjtu.edu.cn
Given the increasing demand for energy consumption, biomass has been more and more important as a new type of clean renewable energy source. Biomass direct firing is the most mature and promising utilization method to date, while it allows a timely solution to slagging problems. Alkali metal elements in the biomass fuel and the ash fusion behavior, as the two major origins contributing to slagging during biomass combustion, are analyzed in this paper. The slag presents various layered structures affected by the different compositions of ash particles. Besides, the high-temperature molten material which provides a supporting effect on the skeletal structure in biomass ash is proposed to evaluate the ash fusion characteristics. In addition, numerous solutions to biomass slagging, such as additives, fuel pretreatment, and biomass co-firing, are also discussed.

Keywords: biomass, slagging, alkali metal, ash fusion, additive

\section{INTRODUCTION}

The rapid depletion of fossil fuels and increasing severity of environmental problems has resulted in the worldwide interest on the utilization of biomass as an environment-friendly energy source of neutral $\mathrm{CO}_{2}$. The World Summit on Sustainable Development in Johannesburg in 2002 accelerated the global exploitation and utilization of biomass. The EU proposed that biomass power generation will eventually provide $15 \%$ of its total power generation, which can meet the needs of 100 million families (Chen, 2012). To accelerate biomass utilization, many countries have strengthened policy guidance and subsidized biomass power plants. For example, China currently grants a $\$ 0.5 / \mathrm{kWh}$ subsidy for biomass power generation, which makes the price of electricity generated from biomass power approximately twice that of coal firing. Since the construction of the first biomass direct combustion power plant in Shanxian in 2006 (Cui et al., 2012), more than 120 biomass power plants have been constructed in China.

Biomass energy sources require conversion prior to use. Thermochemical conversion methods, such as direct firing, gasification, and liquefaction, and bioconversion methods, such as fermentation, are the current major methods of biomass utilization nowadays (Jiang, 2007). Biomass gasification technology uses plant biomass to produce $\mathrm{CO}, \mathrm{CH}_{4}, \mathrm{H}_{2}$, and other combustible gases. This technology not only reduces environmental pollution, but also improves utilization (Wang et al., 2010a). Italy has developed a 12-MW biomass IGCC program demonstration project, which achieves a power efficiency of $31.7 \%$. Sweden is currently testing pressure gasification technology. China had set up over $20 \mathrm{MW}$ biomass power systems and $4 \mathrm{MW}$ demonstration projects for straw gasification power generation by 2006 (Wu et al., 2013).
Jiang et al. (2012) investigated the catalytic gasification of biomass and pointed out that, with the use of catalysts, conversion efficiency can be increased by $10 \%$. However, a considerable amount of tar was generated during gasification, and the energy in the tar consumed up 5-15\% of the total energy. Further research should focus on better catalysts and tar removal.

Biomass liquefaction chemically converts biomass to liquid products. Some direct liquefaction methods convert biomass to oil products in a high-pressure instrument, whereas indirect liquefaction involves further processing gasification products into liquid products (Jiang, 2007). The direct ultrashort contact liquefaction technology developed by the University of Western Ontario in Canada has a low cost of production of $50 \mathrm{CAD} / \mathrm{t}(\$ 48 / \mathrm{t})$ in largescale industrial manufacture, which is a major breakthrough in biomass liquefaction. The University of Tuebingen in Germany has developed a pyrolysis device for low temperatures to deal with urban waste (Sun et al., 2006). The Solar Energy Research Institute has set up an experimental biomass pyrolysis facility with various crafts; the oil yield rate of this facility can reach 70\% (Cook and Beyea, 2000). However, biomass liquefaction in general faces two major challenges: high cost and immature purification techniques (Yang et al., 2013).

Pyrolysis is a kind of direct liquefaction that can be conducted under atmospheric pressure. It is the decomposition of organic matter when biomass is heated in the absence of oxygen. During the process, a hydrocarbon gas mixture, an oil-like liquid, and a solid char residue are correspondingly produced (Demirbas, 2004). Pyrolysis is also the first step in the combustion model of solid fuel particles, followed by volatile and char combustion (Williams et al., 2012). 
Besides, alga has broad development prospects for its advantages of large amount, short growth cycle, and high content of lipid, which make it appropriate material of producing liquid fuel. America has realized the strategic importance of renewable energy since 1970s, and thus put large human and material resources into alga energy research and development (Sheehan et al., 1998). While in combustion, the fusion temperature of alga are relatively low, therefore the melting point of ash obtained at low temperature $\left(530^{\circ} \mathrm{C}\right)$ is more convincing. The slagging and ash fusion characteristics (AFC) vary with the fuel type (Wang et al., 2008a,b). China started late in this area and lagged developed countries on technical level. Further study should integrate the environment situation to enlarge the range of application, and focus on advanced technology (Li et al., 2012).

Biomass direct firing is still the most mature and promising utilization method (Arias et al., 2008; Wang et al., 2010b). High volatile matter, low ash matter, low $\mathrm{N}$ and $\mathrm{S}$ content, and $\mathrm{CO}_{2}$ "zero emission" make biomass a premium fuel (Xiao et al., 2003). The resulting ash can be used directly as potash fertilizer or processed into compound fertilizer. Nordic countries have developed mature biomass direct firing technology after years of research. The first straw-firing power plant was established by BWE company, Denmark in 1988. Over 130 straw-firing power plants are in operation in Denmark, and the technology has been generalized to other European countries, such as Sweden and Finland. In the USA, the GE company has developed large-scale circulating fluidized bed boiler for wood waste combustion using the Lurgi process. Fluidized bed boilers that use firewood as feedstock were developed by B\&W company and went into operation in the late 1980s (Steininger and Voraberger, 2003).

In spite of the advantages of biomass firing, it also faces many challenges as a main means of biomass utilization. Fouling and slagging threaten the economy and long-term operation security of biomass power plants (Vamvuka et al., 2008; Pettersson et al., 2009). For example, some newly built power plants in Northern China have to shut down and clean the boiler every 20-30 days because of slagging in the intermediate-temperature superheater. Serious slagging also occurs on or near the bag filters of some boilers (Niu et al., 2010a).

A high concentration of $\mathrm{K}$ in biomass fuel tends to result in the easy formation of compounds with low melting points. The absorption of particles on compounds leads to severe slagging and fouling in flues or on heating surfaces, which in turn leads to major limitation of biomass utilization (Wei et al., 2005; Broström et al., 2007; Elled et al., 2010; Kassman et al., 2011; Vainio et al., 2013). $\mathrm{Cl}$ can promote the release of $\mathrm{K}$ in the form of $\mathrm{KCl}_{\mathrm{g}}$. The condensation of vapor-phase alkali compounds generates deposits on the heating surface (Aho and Ferrer, 2005). Si, Al, and S can trap alkali compounds before being deposited, thereby reducing the alkali content (Niu et al., 2010a). Alkali metal content in biomass fuel has a major effect on slagging. Vamvuka (2009) have shown that alkali index (AI) can be used as a criterion for biomass slagging instead of the criterion used for coal firing. AI reflects the quantity of the alkali oxides in the fuel per unit of fuel energy, and when the AI value exceeds 0.34 , the fuel tends to undergo slagging.

The AFC of biomass also affect slagging. The evolvement of elements in ash directly affects the slagging in the boiler. Niu et al. (2010b) examined the AFC of capsicum, cotton, and wheat stalks and noted that the evaluation index used for the AFC of coal is not suitable for biomass ash. The evaluation of biomass should be based on high-temperature molten material formed in ash. Biomass fuel characteristics depend on its species properties, the growth environment, and fertilizer type; as a result, the AFC of various biofuels differ from each other.

Extensive studies have been conducted on the biomass slagging process and mechanism. A study on slagging in a biomass boiler in Northern China has shown that the slag presents a layered structure, particularly in the intermediate-temperature superheater (Niu et al., 2010c). $\mathrm{NH}_{4} \mathrm{Cl}$ crystals were found at the exit of the bag filter of the biomass power plant. The presence of these crystals was attributed to the high $\mathrm{Cl}$ content in the biomass fuel produced from local fertilizer. In addition, the soil was not cleaned up during collection, leading to the release of $\mathrm{NH}_{4} \mathrm{Cl}$ during combustion and condensation as well as deposition at the tail of gas flue (Niu et al., 2012).

Thus, two major causes contribute to slagging during biomass combustion: (1) crystal precipitation of alkali metal elements in the biomass fuel and (2) ash fusion during biomass combustion. Solving the slagging problem should begin with these two aspects. Based on the background mentioned above, this review describes the research progress of these two problems inducing biomass slagging, and further discusses several countermeasures working in different mechanisms.

\section{BIOMASS SLAGGING MECHANISMS}

Significant theoretical and experimental study has been performed on biomass slagging. Slag on the furnace wall and superheater is attributed to fine ash particles with high $\mathrm{Cl}$ and $\mathrm{K}$ content (Johansson et al., 2008). Cl can promote the release of $\mathrm{K}$ in biomass, resulting in the formation of $\mathrm{KCl}$, which then condenses on the surface of sub-micrometer particles in the flue gas or heating surfaces. The $\mathrm{KCl}$ bonds slags formed later with the tube acting as adhesive (Aho, 2001). Deposition and slagging conditions during combustion relate closely with the content of risk elements, such as $\mathrm{Na}, \mathrm{Cl}$, and $\mathrm{K}$, and protective elements, such as Si, Al, and S (Aho and Ferrer, 2005; Xiong et al., 2008; Niu et al., 2010a).

A schematic mechanism of slagging is shown in Figure 1. In biomass-fired furnaces, $\mathrm{Cl}$ and $\mathrm{K}$ first combine into $\mathrm{KCl}(\mathrm{g})$, which then condenses on heating surfaces by various mechanisms, such as diffusion, electrophoresis, thermophoresis, inertial impaction, and gravity, with coarse fly ash or mineral salt on the tube acting as adhesive bonding. Partial $\mathrm{KCl}$ may be sulfated, which promotes slagging, whereas partial $\mathrm{KCl}$ can be aluminosilicated and inhibits slagging. Co-firing, additives, and leaching can change the components of the fuels and further affect combustion and slagging. During co-firing, the addition of additives, or leaching, if the $(\mathrm{K}+\mathrm{Cl}) /(\mathrm{Si}+\mathrm{Al})$ ratio in the fuels increases, the $\mathrm{KCl}$ concentration increases, and slagging is exacerbated, whereas if the $(\mathrm{K}+\mathrm{Cl}) /(\mathrm{Si}+\mathrm{Al})$ ratio decreases, more $\mathrm{KCl}$ is trapped by $\mathrm{Si}$ and $\mathrm{Al}$ and slagging weakens.

Thus, the crystal precipitation behavior of alkali metal elements and ash fusion behavior are shown to be the two main causes of slagging during biomass combustion. 


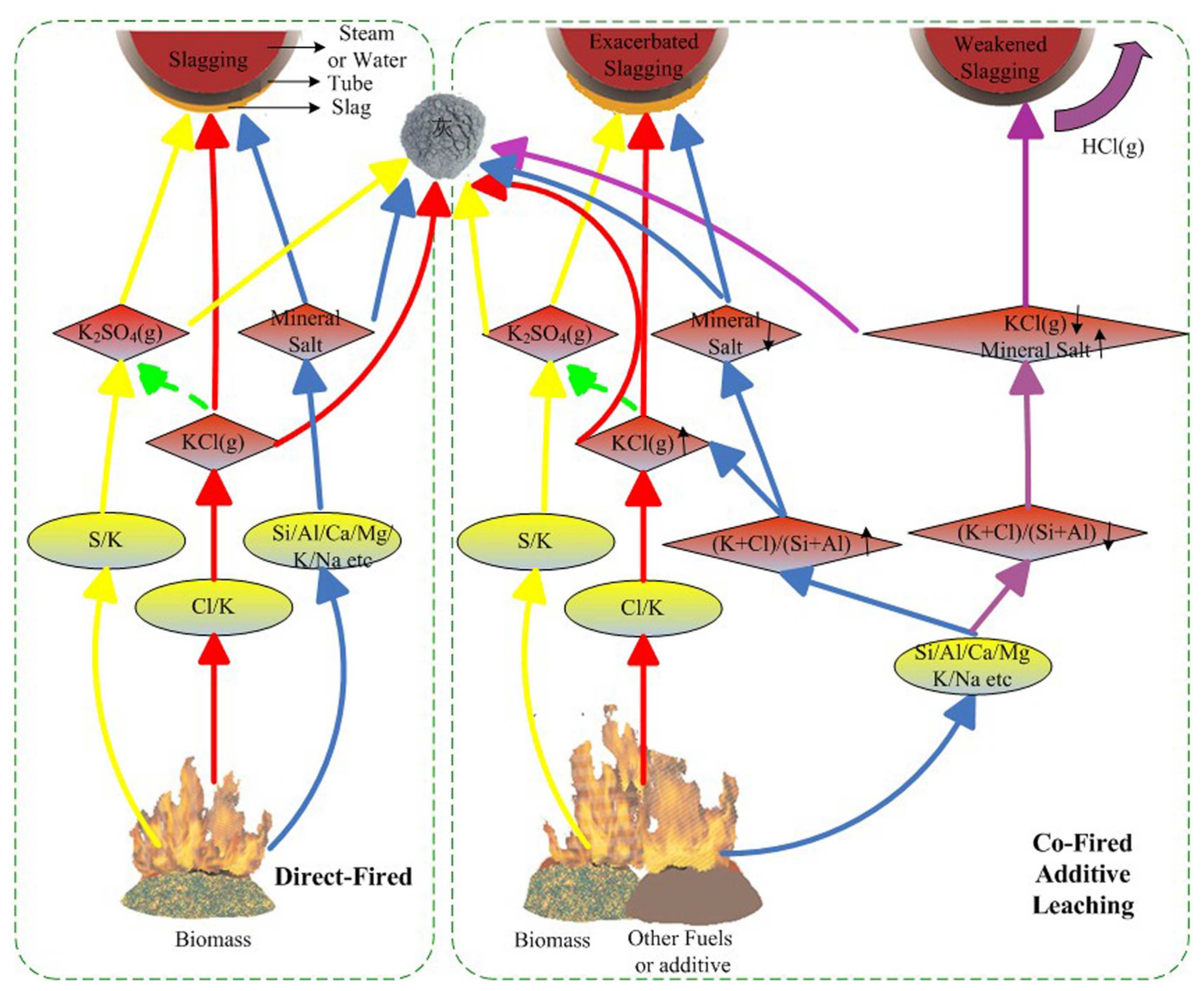

FIGURE 1 | Schematic diagram of the slagging mechanism in biomass-fired furnaces

\section{CRYSTAL PRECIPITATION OF ALKALI METAL ELEMENTS}

A high concentration of $\mathrm{K}$ in biomass fuel tends to result in the easy formation of compounds with low melting points, and leads to severe slagging and fouling in flues or on heating surfaces. A portion of the soluble $\mathrm{K}$ turns into gas during combustion and escapes with the flue gas, while some forms insoluble $\mathrm{Si}-\mathrm{Al}$ compounds (Niu et al., 2010a). The gas-phase K condenses on hot surfaces, and the flue gas forms deposits and slag, which severely limit biomass utilization.

Ma et al. (2011) performed experiments on the combustion of three different kinds of straw in a muffle at five different temperatures. The results indicated that $\mathrm{KCl}$ and $\mathrm{K}_{2} \mathrm{SO}_{4}$ are the main forms of alkali metals in the rice straw bottom ashes combusted at $700^{\circ} \mathrm{C}$, whereas the glassy compounds $\mathrm{K}_{2} \mathrm{MgSi}_{5} \mathrm{O}_{12}$ and $\mathrm{KAISi}_{3} \mathrm{O}_{8}$ are the main alkali metals in rice straw bottom ashes combusted above $750^{\circ} \mathrm{C}$. The alkali metal content is lowest in rice straw bottom ashes, but its slagging is the most serious. Ma et al. (2011) concluded that the degree of slagging of straw ash at low combustion temperatures is related with alkali metal content and $\mathrm{KCl} / \mathrm{K}_{2} \mathrm{SO}_{4}$ ratio. At higher combustion temperatures, the degree of slagging is mainly determined by glassy compounds derived from $\mathrm{SiO}_{2}, \mathrm{~K}_{2} \mathrm{O}, \mathrm{Al}_{2} \mathrm{O}_{3}$, and other metallic oxides.
To further study the process and mechanism of alkali precipitation slagging, Niu et al. (2010c) collected slag samples formed in fourth-, second-, and first-stage superheaters (SH4, SH2, and $\mathrm{SH} 1$ ) in a 12-MW biomass-fired grate furnace in the Bachu biomass power plant in China (The slag on the third-stage superheater was very thin and therefore not collected during the work.). After 2 weeks of operation, slag (Figure 2) was collected, sampled, and analyzed. The morphological characteristics and composition of the collected slag samples are shown in Table 1.

As shown in Table 1, the slag in the high-temperature superheater is found to be loose and porous, with high concentrations of $\mathrm{Si}$ and $\mathrm{Al}$ attributed to the existence of $\mathrm{Ca}\left(\mathrm{Mg}_{x} \mathrm{Al}_{y}\right)\left(\mathrm{Si}_{m} \mathrm{Al}_{n}\right) \mathrm{O}_{6}$. The aluminosilicate has a high melting point and is unlikely to become liquid and stick to the surfaces of the superheater, even when the temperature is relatively high. Therefore, the slag of the fourth-stage superheater is relatively small and caducous.

The slag on the intermediate-temperature superheater presents a clear layered structure with different hardness and colors. The compositions of each layer are shown in Table 2.

As is shown in Table 2, compositions of each layer present variety. $\mathrm{SiO}_{2}$ is found in transition layer, while new compositions such as akermanite, gehlenite, and monticellite are generated in alternating layer. The formation process of each layer has been 


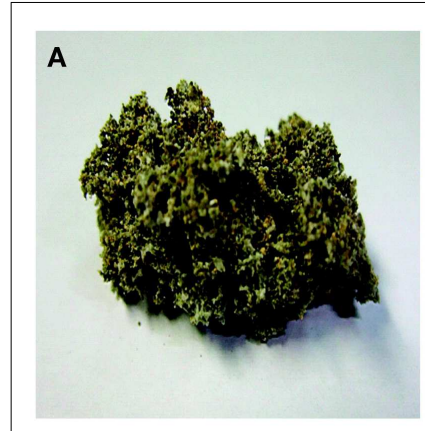

Slag on the fourth stage super-heater

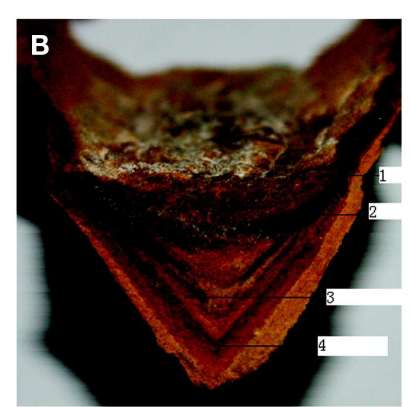

Slag on the secondary super-heater

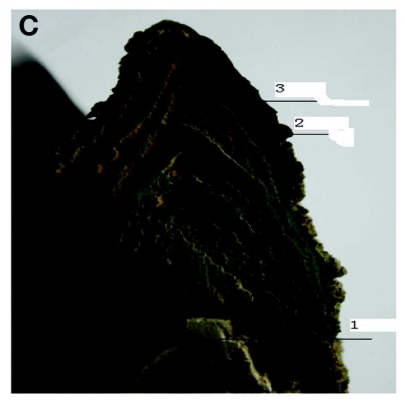

Slag on the primary super-heater

FIGURE 2 | Slag samples from the boiler. (A) Slag on SH4. (B) Slag on SH2. (C) Slag on SH1.

Table 1 | Slag composition in superheater.

\begin{tabular}{|c|c|c|c|}
\hline Position & Morphology & Thickness & Major composition \\
\hline $\mathrm{SH} 4$ & Porous & $<1 \mathrm{~cm}$ & $\left.\mathrm{KAISi}_{2} \mathrm{O}_{6}, \mathrm{Ca}\left(\mathrm{Mg}_{x} \mathrm{Al}_{y}\right)\left(\mathrm{Si}_{m} \mathrm{Al}\right)_{n}\right) \mathrm{O}_{6}$ \\
\hline $\mathrm{SH} 2$ & $\begin{array}{l}\text { Layered } \\
\text { structure }\end{array}$ & $90 \mathrm{~cm}$ & $\begin{array}{l}\mathrm{KCl}, \mathrm{NaCl}, \mathrm{K}_{2} \mathrm{Ca}_{2}\left(\mathrm{SO}_{4}\right)_{3}, \mathrm{SiO}_{2} \\
\mathrm{Ca}\left(\mathrm{Mg}_{x} \mathrm{Fe}_{y}\right) \mathrm{SiO}_{4} \\
\left(\mathrm{Ca}_{m} \mathrm{Na}_{n}\right)\left(\mathrm{Mg}_{x} \mathrm{Al}_{y} \mathrm{Fe}_{z}\right) \mathrm{SiO}_{4}\end{array}$ \\
\hline $\mathrm{SH} 1$ & $\begin{array}{l}\text { Layered } \\
\text { structure }\end{array}$ & $<10 \mathrm{~cm}$ & $\begin{array}{l}\mathrm{KCl}, \mathrm{NaCl}, \mathrm{CaSO}_{4}, \mathrm{SiO}_{2} \\
\mathrm{~K}_{3} \mathrm{Na}\left(\mathrm{SO}_{4}\right)_{2}, \mathrm{Na}_{0.1008} \mathrm{~K}_{0.8998} \mathrm{Cl}\end{array}$ \\
\hline
\end{tabular}

Table 2 | Slag composition in the intermediate-temperature superheater.

\begin{tabular}{ll}
\hline Layer & Major composition \\
\hline Bottom layer & $\mathrm{KCl}, \mathrm{NaCl}, \mathrm{K}_{2} \mathrm{Ca}_{2}(\mathrm{SO} 4)_{3}$ \\
Transition layer & $\mathrm{KCl}, \mathrm{NaCl}, \mathrm{SiO}_{2}$ \\
Alternating layer (yellow) & $\mathrm{KCl}, \mathrm{NaCl}, \mathrm{SiO}_{2}$, akermanite, gehlenite, \\
& monticellite \\
Alternating layer (brown) & $\mathrm{KCl}, \mathrm{NaCl}, \mathrm{SiO}_{2}$, akermanite, gehlenite
\end{tabular}

discussed extensively. The flue gas temperature in the secondary superheater ranges from 507 to $645^{\circ} \mathrm{C}$, resulting in $\mathrm{KCl}$ and $\mathrm{NaCl}$ condensation, adherence onto the heating surfaces, and formation of the bottom layer. The sticky sylvine can trap the coarse large ash particles mainly containing $\mathrm{Si}, \mathrm{Al}$, and $\mathrm{Ca}$, which further promotes the development of the slag. This trend explains the considerable amount of quartz contained in the transition layer. In the alternating yellow and brown layers, the monticellite that contains more $\mathrm{Mg}$ than $\mathrm{Fe}$ is yellow, whereas the monticellite that contains less $\mathrm{Mg}$ than $\mathrm{Fe}$ is brown. The yellow layer, where fine particles with highly concentrated $\mathrm{Na}, \mathrm{K}, \mathrm{S}$, and $\mathrm{Cl}$ are deposited, generates sticky matters to trap coarse large ash particles and then forms the brown layer. The brown layer becomes yellow after the adhesive capacity and reunion of fine particles have decreased. The circulation of this process leads to the formation of the alternating layer.

The slag on the low temperature superheater presents a clear breakable layer structure, which is similar to that on the secondary superheater. Layers 1, 2, and 3 correspond to the bottom, alternating pale-yellow and black layers, respectively. The slag on the low temperature superheater has a formation mechanism similar to the intermediate-temperature superheater slag, but has a different color. Liu et al. (2011) showed that, during the operation of the biomass boiler, low melting salts precipitate on the surface of tube because of the flue gas temperature and lead to severe slagging on the intermediate-temperature superheater.

Under the temperature condition of intermediate-temperature superheater, sticky $\mathrm{KCl}$ and $\mathrm{K}_{3} \mathrm{Na}\left(\mathrm{SO}_{4}\right)_{2}$ are formed. These particles trap fly ash particles and allow slags to adhere onto the surface. These factors also result in the transition layer formation; however, the colors are different because the compositions differ. The formation of alternating layers can be described as follows: $\mathrm{K}_{3} \mathrm{Na}\left(\mathrm{SO}_{4}\right)_{2}$ traps other particles to form the initial layer, which is bonded by the sticky $\mathrm{KCl}$. These results indicate the universality of layered slagging structure of the biomass-fired boiler.

The slagging problem in the Bachu biomass power plant is more severe than that of the Sheyang biomass power plant. The comparison of biomass fuel and ash samples indicates that a low concentration of $\mathrm{Cl}$ in Sheyang cotton stalks reduces the formation of $\mathrm{KCl}$, whereas high concentrations of $\mathrm{Si}$ and $\mathrm{Al}$ in ash tend to trap alkali chloride. Sulfur is volatile in Sheyang cotton stalks, and volatile $\mathrm{SO}_{2}$ and $\mathrm{SO}_{3}$ can react with $\mathrm{KCl}$ and form sulfate, which has weaker effects on slagging. This situation proposes a method for dealing with slagging problem by changing element proportions in the fuel.

\section{ASH FUSION CHARACTERISTICS OF BIOMASS}

Ash fusion characteristics also affect slagging characteristics (Werkelin et al., 2011). Biomass ash is the inorganic residue of biomass thermal-chemical utilization. Ash content increases in the biomass during the plant growth, and is affected by biomass species, origin, soil, and other factors (Knudsen et al., 2004; Wiesenthal et al., 2006; Yan and Chen, 2007; Xiong et al., 2008; Dong et al., 2009; Gao et al., 2009). The abbreviations used in this section are listed in Table 3.

Biomass ash fusion temperature varies depending on the diversity of biomass types. The softening temperature (ST) of wood biomass is on average $950-1000^{\circ} \mathrm{C}$ (Heinzel et al., 1998), whereas that of straw biomass is about $1000^{\circ} \mathrm{C}$ (Llorente and Garcia, 2005). Herb biomass has a lower initial deformation temperature (IDT) of $730^{\circ} \mathrm{C}$. The ST of some seaweed biomass is $<800^{\circ} \mathrm{C}$ (Wang et al., 2008a). According to the ash fusion temperature statistics collected by Chen and Jiang (1995), over a thousand coal samples, biomass 
Table 3 | Abbreviations used in the section.

\begin{tabular}{cl}
\hline Abbreviation & \multicolumn{1}{c}{ Explanation } \\
\hline AFC & Ash fusion characteristics \\
IDT & Initial deformation temperature \\
ST & Softening temperature \\
HT & Hemispheric temperature \\
FT & Fluid temperature \\
CNS & Cotton stalks \\
WTS & Wheat stalks \\
CMS & Capsicum stalks \\
\hline
\end{tabular}

generally has a lower ash fusion temperature than coal because of the high volatile matter and $\mathrm{Cl}$ content in biomass and the high $\mathrm{K}$ content in ash. Besides, several frequently used coal ash fusion criteria are shown in Table 4 (Ai et al., 1994; Mao et al., 2003; Masia et al., 2007). However, the biomass fusion slagging characteristics calculated based on these criteria of coal fusion, such as base/acid ratio, $\mathrm{Si}-\mathrm{Al}$ ratio, and slag viscosity index, do not reflect the practical results, indicating the inadaptability of coal ash fusion criteria to biomass ash.

Li et al. (2009) noted that various types of biomass should be treated differently when using ash fusion temperature to judge the slagging trend. Furnace exit temperature is limited by the ash fusion temperature of the biomass used, and is thus required to be $50-100^{\circ} \mathrm{C}$ lower than the IDT of biomass ash. Furthermore, slagging evaluation based on coal slagging criteria are inaccurate. High $\mathrm{K}$ content in ash lowers fusion temperature. AI, which is the amount of alkali oxides in the fuel per unit of fuel energy, was proposed to predict the slagging trend, which agrees with the conclusions reached by Vamvuka (2009).

Li et al. (2013) from Tsinghua University described ash fusion temperature as an important criterion for determining furnace exit temperature. Nine different types of biomass fuels were used in their study on ash fusion temperature. Twenty-seven simulated ashes prepared with mixtures of organic and inorganic oxides were designed to serve as comparisons. The biomass fuel ashes underwent standardized ashing procedures at $580^{\circ} \mathrm{C}$ as per ASTM 870 codes and $815^{\circ} \mathrm{C}$ as per Chinese GB/T 212 codes. The XRD pattern of one ash showed that the alkali were present in different forms. $\mathrm{K}_{2} \mathrm{Ca}\left(\mathrm{CO}_{3}\right)_{2}$ and $\mathrm{KCl}$ were the major phases for $580^{\circ} \mathrm{C}$, leading to a low IDT. $\mathrm{KCl}, \mathrm{CaO}$, and $\mathrm{MgO}$ were the major phases for $815^{\circ} \mathrm{C}$, which contributed to a significantly higher IDT of $1500^{\circ} \mathrm{C}$. Reducing the amount of compounds with low melting points led to a rapid increase in ash fusion temperature. At the same time, the high melting point of $\mathrm{CaO}$ and $\mathrm{MgO}$ played a supporting role in the skeleton. High $\mathrm{K}$ content can hypothetically increase the fusion temperature. By contrast, the ash fusion test cannot correctly predict ash slagging and deposition trends for the samples with high $\mathrm{K}$ content, because $\mathrm{K}$ is released during the ashing procedure under ash fusion test conditions. During combustion in the boiler, gas-phase $\mathrm{K}$ tended to condense and deposit on heating surfaces and degrade the slagging status. Furthermore, $\mathrm{Al}_{2} \mathrm{O}_{3}$ remarkably increased the IDT in the simulated ash test. The lower IDT of practical ash compared with simulated ash was attributed to the molten material in the former. Base/acid ratio (B/A) was
Table 4 | Several frequently used criteria for coal ash fusion evaluating.

\begin{tabular}{|c|c|c|c|}
\hline Index & Expression/wt\% & Slag & ing degree \\
\hline $\begin{array}{l}\text { Base/acid } \\
\text { ratio }(B / A)\end{array}$ & $\begin{array}{l}\left(\mathrm{Fe}_{2} \mathrm{O}_{3}+\mathrm{CaO}+\mathrm{MgO}+\right. \\
\left.\mathrm{Na}_{2} \mathrm{O}+\mathrm{K}_{2} \mathrm{O}\right) /\left(\mathrm{SiO}_{2}+\right. \\
\left.\mathrm{Al}_{2} \mathrm{O}_{3}+\mathrm{TiO}_{2}\right)\end{array}$ & $\begin{array}{l}<0.206 \\
0.206-0.4 \\
>0.4\end{array}$ & $\begin{array}{l}\text { Slight } \\
\text { Moderate } \\
\text { Severe }\end{array}$ \\
\hline $\begin{array}{l}\text { Slag } \\
\text { viscosity } \\
\text { index (G) }\end{array}$ & $\begin{array}{l}\mathrm{SiO}_{2} /\left(\mathrm{SiO}_{2}+\mathrm{Fe}_{2} \mathrm{O}_{3}+\right. \\
\mathrm{CaO}+\mathrm{MgO}) \times 100\end{array}$ & $\begin{array}{l}72-80 \\
65-72 \\
50-65\end{array}$ & $\begin{array}{l}\text { Slight } \\
\text { Moderate } \\
\text { Severe }\end{array}$ \\
\hline Si-Al ratio & $\mathrm{SiO}_{2} / \mathrm{Al}_{2} \mathrm{O}_{3}$ & $\begin{array}{l}<1.87 \\
2.56-1.87 \\
>2.56\end{array}$ & $\begin{array}{l}\text { Slight } \\
\text { Moderate } \\
\text { Severe }\end{array}$ \\
\hline $\begin{array}{l}\text { Fouling } \\
\text { index (Fu) }\end{array}$ & $\mathrm{B} / \mathrm{A} \times\left(\mathrm{Na}_{2} \mathrm{O}+\mathrm{K}_{2} \mathrm{O}\right)$ & $\begin{array}{l}<0.6 \\
0.6-40 \\
>40\end{array}$ & $\begin{array}{l}\text { Slight } \\
\text { Severe } \\
\text { Extremely severe }\end{array}$ \\
\hline $\begin{array}{l}\text { Slagging } \\
\text { index (Rs) }\end{array}$ & $\begin{array}{l}\mathrm{Rs}=(\mathrm{B} / \mathrm{A}) \times \mathrm{Sd}, \mathrm{Sd}=\% \\
\text { of } \mathrm{S} \text { in dry fuel }\end{array}$ & $\begin{array}{l}<0.6 \\
0.6-2.0 \\
2.0-2.6 \\
>2.6\end{array}$ & $\begin{array}{l}\text { Slight } \\
\text { Moderate } \\
\text { Severe } \\
\text { Extremely severe }\end{array}$ \\
\hline $\begin{array}{l}\text { Chlorine } \\
\text { contain }\end{array}$ & $\mathrm{Cl}$ content as received & $\begin{array}{l}<0.2 \\
0.2-0.3 \\
0.3-0.5 \\
>0.5\end{array}$ & $\begin{array}{l}\text { Slight } \\
\text { Moderate } \\
\text { Severe } \\
\text { Extremely severe }\end{array}$ \\
\hline $\begin{array}{l}\text { Alkali index } \\
\text { (Al) }\end{array}$ & $\begin{array}{l}\left(\mathrm{Na}_{2} \mathrm{O}+\mathrm{K}_{2} \mathrm{O}\right) \mathrm{kg} / \mathrm{GJ} \\
\mathrm{Na}_{2} \mathrm{O} \\
\mathrm{Na}_{2} \mathrm{O}+\mathrm{K}_{2} \mathrm{O}\end{array}$ & $\begin{array}{l}0.17-0.34 \\
>0.34 \\
<2.0 \\
>2.0 \\
<3.5 \\
>3.5\end{array}$ & $\begin{array}{l}\text { Probable } \\
\text { Certain to occur } \\
\text { Slight } \\
\text { Severe } \\
\text { Slight } \\
\text { Severe }\end{array}$ \\
\hline
\end{tabular}

also used to help determine the slagging trend. A B/A value of 1.4 resulted in the lowest IDT of $800^{\circ} \mathrm{C}$.

To investigate the effect of ashing temperatures and other factors on AFC, Niu et al. (2011) examined capsicum stalk ashes using XRF, XRD, DT/DTG, and ash fusion temperature tests. Samples prepared by ashing at 400,600 , and $815^{\circ} \mathrm{C}$ were heated using an experimental SJY Image-Melt Point apparatus. The results are shown in Figure 3. The fusion processes of three kinds of ashes all exhibited four fusibility characteristic shapes: initial deformation, softening, hemispherical, and fluid, with an obvious narrowing in the heating process. No significant changes in characteristics temperature were observed with increased ashing temperature.

When the ash was heated up to about $1100^{\circ} \mathrm{C}$, the compositions of the three kinds of ashes remained basically the same. Certain substances with high melting points supported the skeletal structure. The fusion characteristics of biomass ash depended on high-temperature molten material, rather than on the proportion of elements in the ash. XRD patterns showed that quartz, potassium iron oxide, periclase, and microcline were the main components of the three kinds of ashes. The high-temperature ash also contained zeolite and calcium silicate.

To determine further evidence to support the AFC evaluation criterion, Niu et al. (2010b) investigated cotton stalks and 


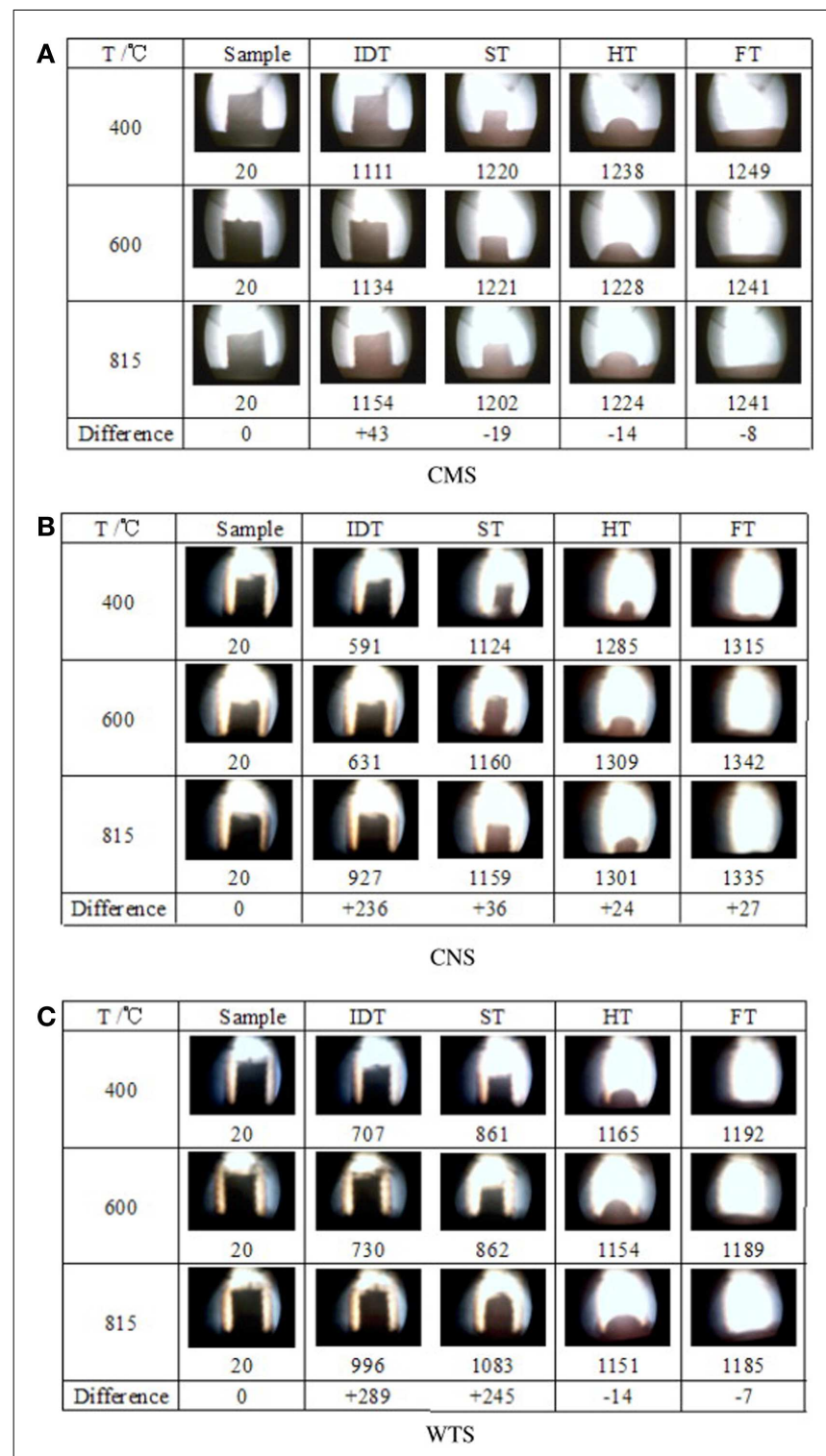

FIGURE 3 | Ash fusion temperatures of CMS (A), CNS (B), and WTS (C).

wheat stalks at the same ashing temperature with capsicum stalks mentioned above. The results of samples are shown in Figure 3, which shows that aside from an increase in IDT, no significant changes in ST, hemispheric temperature (HT), and fluid temperature (FT) were observed with increasing ashing temperature. Regardless of ashing temperature, the compositions of the CMS, $\mathrm{CNS}$, and WTS ashes were the same after 1100,1100 , and $1150^{\circ} \mathrm{C}$, respectively. These results agree with those of the study on capsicum stalks above. Aside from IDT, the other three kinds of AFC were slightly affected by the ashing temperature and the elemental composition of the ash. This phenomenon indicated that the evaluation of the biomass AFC should not be based solely on the proportion of elements except IDT, but also on the hightemperature molten material that supports the skeleton structure of the biomass ash.
To date, no global unified standard for biomass ashing temperature as a research basis of biomass ash characteristics has been established. Ashing temperature of the US ASTM/E870-82 is $600^{\circ} \mathrm{C}$ for $40 \mathrm{~min}$, whereas that of the $\mathrm{EU}$ is $550 \pm 10^{\circ} \mathrm{C}$. Corresponding national standards have not been issued in China, where the ashing of biomass follows the coal quality analysis standard (GB/T212-2001), with an ashing temperature of $815 \pm 10^{\circ} \mathrm{C}$ for $40 \mathrm{~min}$. Thy et al. (2009) and Arvelakis and Frandsen (2007) adopted $525^{\circ} \mathrm{C}$ as the ashing temperature for sawdust, wheat straw, and rice straw. Except for the loss of $\mathrm{K}$ in sawdust and $\mathrm{Cl}$ in wheat straw, the loss of the remaining elements could be ignored. Wang et al. (2008a) studied the fusion characteristics of seaweed ash and found that the melting point of seaweed ash was low; neither China's national standard (GB/T212-2001) nor the US ASTM standard was suitable for seaweed biomass. These results show that the melting point of biomass ash is significantly lower than that of coal ash, which makes the ashing temperature of coal not suitable for biomass. At present, $550^{\circ} \mathrm{C}$ in EU's SS-ISO 540 seems relatively suitable. The operation procedures of ash fusion test (SS-ISO 540) are shown as follows: the ashes of the used fuel are obtained in a muffle furnace at $550^{\circ} \mathrm{C}$ for $40 \mathrm{~min}$. And during the ash fusion test, the IDT, ST, HT, and FT are identified from an ash cylinder. The heat treatment of the ash cylinders was done in an oxidizing atmosphere (air) with a heating rate of $8^{\circ} \mathrm{C} / \mathrm{min}$. The deformation temperature, IDT, is then used for comparison with the actual slagging tendency obtained from the combustion experiments (Gilbe et al., 2008).

In summary, the study on biomass AFC is important, particularly on the ashing temperature and high-temperature AFC. Selecting the appropriate ashing temperature and furnace exit temperature during combustion has a significant effect on slagging. Further study should be performed on the structure of high-temperature molten material during the ash fusion process.

\section{SOLUTIONS TO BIOMASS SLAGGING}

Given the enormous obstacle of slagging in biomass combustion, numerous studies have been performed to prevent slagging. At present, the main solutions to solving slagging problem consist of the use of additives, fuel pretreatment, and co-firing (Tang, 2013).

\section{ADDITIVES}

Several authors have proposed using various types of mineral additives to solve the deposition problems, and they have been successful to some extent. $\mathrm{Kaolin}\left(\mathrm{Al}_{2} \mathrm{O}_{3} \cdot 2 \mathrm{SiO}_{2}\right)$ can decrease the amount of $\mathrm{KCl}$ released during co-combustion with biomass (Wei et al., 2005), and as a result, significantly reduce superheater deposits and slagging, consequently enhancing the operation of the biomass-fired boiler (Jensen et al., 1997; Davidsson et al., 2007, 2008). Wilen et al. (1987) noted that the addition of a powdery additive, kaolin, talc, and ceramic feldspar would increase the fusion temperature. Although this addition would increase the cost of pellets by $5 \%$ and the ash content, thereby lowering the heating value, it would also result in cheaper maintenance and equipment cost. Steenari and Lindqvist (1998) found that compared with dolomite and calcilutite, kaolin, with a large amount of Si-Al compounds, can react with vapor-phased alkali halide and reduce the slagging of biomass fuel, which makes it the most 
effective additive. Slag formation could actually be decreased by $50 \%$ with kaolin addition based on the results obtained by Xiong et al. (2008).

However, kaolin is relatively expensive, and its addition may lead to higher operating cost. In fact, few power plants use kaolin as a long-term additive. Finding substitutes for kaolin has attracted much interest. Soil also contains a lot of $\mathrm{Si}-\mathrm{Al}$ compounds, such as montmorillonite, illite, kaolin, quartz, and white mica. Studies have predicted that soil might have a similar function on $\mathrm{K}$ fixation with kaolin after being mixed with biomass. Laterite, which is widely distributed in China and Australia, may have higher economic value than kaolin as an additive for biomass because of its low cost and easy availability.

Biomass is inevitably contaminated by soil and ash during harvest or transportation, and not all kinds of soil can be used as additives. For example, alkaline soil can lead to more severe slagging. Niu et al. (2012) accidentally found $\mathrm{NH}_{4} \mathrm{Cl}$ (Figure 4) at the exit of bag filter of a serious slagging biomass-fired boiler. This $\mathrm{NH}_{4} \mathrm{Cl}$ was attributed to the high content of $\mathrm{Cl}$ in biomass fuel (cotton stalks) from the local fertilizer. Moreover, the soil was not cleaned during collection. These factors led to the release of $\mathrm{NH}_{4} \mathrm{Cl}$ during combustion and the condensation and deposition at the tail of gas flue. Therefore, any factor that may lead to the change in elemental proportions in fuel should be regarded seriously, particularly the often overlooked soil adulterant.

\section{BIOMASS FUEL PRETREATMENT}

Fuel pretreatment before entering the furnace can partially remove risk elements of slagging. Water washing and acid pickling can both remove the $\mathrm{Cl}$ and alkali metal elements (Turn et al., 1997; Aho and Ferrer, 2005; Werkelin et al., 2010). Leaving biomass in the cropland for a while after the harvest can achieve part of the washing effect, but manual washing certainly has better effect and higher economy. Carrillo et al. (2014) noted that a 3.2\% increase in $\mathrm{MJ} / \mathrm{kg}$ occurred after a single wash under $20^{\circ} \mathrm{C}$ compared with the untreated check and a $63 \%$ decrease of alkali content through three steps of washing. However, the addition of water into the biomass as pretreatment is debatable because of the energy input required to dry the biomass prior to combustion. Additionally, the probability of using leachate as fertilizer after washing should be studied. Deng et al., 2010 reported that washing can effectively remove $60-90 \%$ of $\mathrm{K}, \mathrm{Na}, \mathrm{Cl}$, and $\mathrm{S}$ from biomass. As the water temperature increases, the removal rates of $\mathrm{K}, \mathrm{Na}$, and $\mathrm{S}$ change
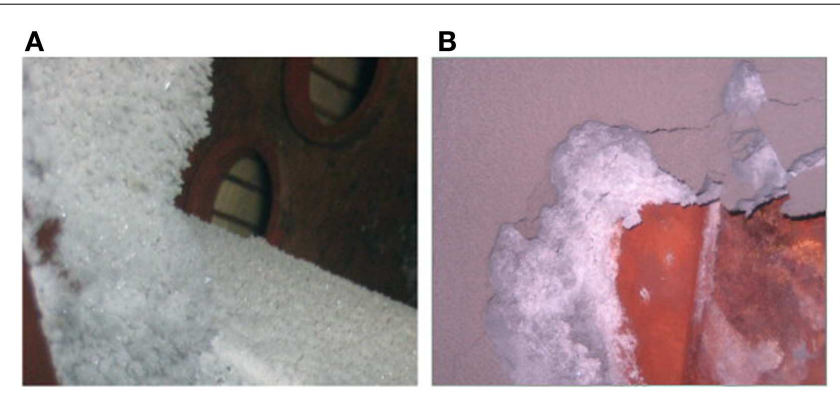

FIGURE 4 | $\mathbf{N H}_{4} \mathbf{C l}$ in the boiler. (A) Slag location. (B) Slag thickness. monotonously, and the slag of wheat straw gradually turns into a short slag.

Moreover, acid pickling can partially remove inorganic composition in biomass. Wang et al. (2008b) used 5\% acids $\left(\mathrm{H}_{2} \mathrm{SO}_{4}\right.$, $\mathrm{HCl}$ ) and distilled water to wash peanut shell samples. The results show that acid pickling can decrease the concentration of alkaline cations in biomass, particularly $\mathrm{K}, \mathrm{Mg}$, and $\mathrm{Ca}$, compared with water washing because of the dissolution of cations in acid. $\mathrm{HCl}$ has the best pretreatment effect.

\section{BIOMASS CO-FIRING}

Co-firing, including combination of different biomass fuel and mix of biomass and coal, has been proposed in numerous studies. The co-firing of biomass and sludge, or the addition of highalumina coal, can both ease slagging on heating surfaces (Turn et al., 1997; Aho and Ferrer, 2005; Khan et al., 2008; Pettersson et al., 2008).

Compared with a dedicated firing of biomass, co-firing has the advantages of low investment and operation cost, low dependence on fuel, and low emission of pollutant. Liu et al. (2011) proposed to add high-alumina coal into biomass fuel, aiming to address the serious slagging of secondary superheater because of high content of alkali metal in the fuel. Xi'an Jiaotong University performed a biomass co-firing experiment in a 300-MW pulverized coal (PC) furnace. A total of $16.1 \mathrm{cal} \%$ of the biomass briquettes was used, and $\mathrm{NO}_{x}$ emission was reduced by $10 \%$. A significantly higher economy was also obtained.

Xu et al. (2013) proposed a new model of agro/forestry residue pellets/shreds and coal co-fired in a large PC furnace as illustrated in Figure 5, on the basis of known innate drawbacks of dedicated firing of biomass, including slagging, corrosion, and the dependence on fuel. First, various agro/forestry residues were collected and pretreated by a crusher and molding machine. Second, the crush and pellet mixtures were transported to power plants. Finally, blends of coal and the pellets/shreds of agro/forestry residues were injected into a specific burner system (top or bottom burner system) after co-milling, and the other burner systems were fed with pure coal. The agro/forestry residues were injected into only one burner system like injection co-firing, whereas these

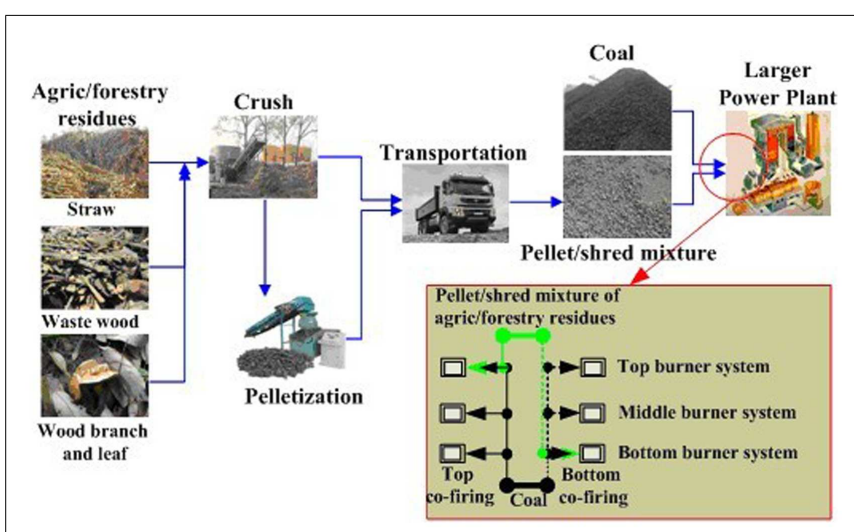

FIGURE 5 | Proposed co-firing model of agro/forestry residues and coal 


\section{Table 5 | Comparison of the three countermeasures of biomass slagging.}

\begin{tabular}{|c|c|c|}
\hline Countermeasure & Advantages & Disadvantages \\
\hline Additives & $\begin{array}{l}\text { Convenient utilization } \\
\text { high efficiency }\end{array}$ & $\begin{array}{l}\text { Decrease in heating } \\
\text { value low economy }\end{array}$ \\
\hline Fuel pretreatment & $\begin{array}{l}\text { Significant removal of } \\
\text { risk elements }\end{array}$ & Cost of fuel drying \\
\hline Biomass co-firing & $\begin{array}{l}\text { Low cost and pollutant } \\
\text { emission high economy }\end{array}$ & $\begin{array}{l}\text { Lack of policy support } \\
\text { (i.e., in China) }\end{array}$ \\
\hline
\end{tabular}

residues were mixed and co-milled with coal before injection like co-milling co-firing. The corresponding technical and economic assessments were performed by co-firing testing in a 300-MW PC furnace and discounted cash flow technique, and the results show that this mode not only can consume agro/forestry residues, ease the fossil fuel crisis, reduce the dependence on fuel, and eliminate slagging in biomass-dedicated firing furnaces, but also results in higher economy and environmental benefits.

Bartolomé et al. (2010) performed co-firing experiments using coal and biomass in a pulverized coal-fired pilot furnace to study ash deposition behavior. The results show that the quantity of collected ash in the deposition probe did not increase noticeably when the biomass share increased to $15 \%$ in terms of energy. However, the opposite was detected in high ash content coal tests. Major components of ash samples were aluminosilicates, which originated from coal clays. These components might act as protective ash coal compounds, but inorganic elements such as $\mathrm{Ca}$ or $\mathrm{K}$ also appeared, and their presence increased with the biomass share. Although $\mathrm{Cl}$ content in cynara was high, this element was not encountered in any of the ash samples collected. Experimental results agree with other experimental studies showing that aluminosilicates from coals may act as protective ash compounds, preventing $\mathrm{Cl}$ deposition on heat transfer surfaces. To conclude, the co-firing of biomass fuel and protective coal with high $\mathrm{Al}$ content may prevent a slagging problem.

In conclusion, the three presented countermeasures of biomass slagging present various advantages and disadvantages that are listed in Table 5 for comparison. Further study should focus on methods to overcoming the disadvantages.

\section{CONCLUSION}

Biomass, as a new type of clean renewable energy source, has played an important role in energy consumption. Direct firing, as the most mature and promising utilization method to date, allows a timely solution to slagging problems. The crystal precipitation of alkali metal elements and ash fusion are generally considered as the two main causes of slagging during biomass combustion. In biomass-fired furnace, $\mathrm{Cl}$ and $\mathrm{K}$ are first combined into $\mathrm{KCl}(\mathrm{g})$, which is then condensed on heating surfaces, and turn into either an adhesive bonding coarse fly ash or a mineral salt on the tube. The slag presents various layered structures affected by the different compositions of ash particles. Slagging problem may be solved by targeting these layered structures as the focus of the research.

Coal ash fusion criteria are not completely suitable to biomass ash. Except for IDT, ST, HT, and FT were slightly affected by ashing temperature and elemental compositions in ash, indicating that evaluation of the biomass AFC should not be simply on the proportion of elements, but also on the high-temperature molten material which provides a supporting effect on the skeletal structure in biomass ash. No unified global standard on biomass ashing temperature has been established. At present, $550^{\circ} \mathrm{C}$ in EU's SS-ISO 540 seems relatively appropriate.

Numerous solutions to biomass slagging have been proposed. The addition of various additives, such as kaolin with a large amount of $\mathrm{Si}-\mathrm{Al}$ compounds, is the most effective solution. Soil has a similar composition with kaolin and may have an impressive K fixation capacity. Therefore, any factor that may lead to the change in the elemental proportions in fuel should be regarded seriously, particularly the often overlooked soil adulterant that is inevitable in biomass collection. Moreover, pretreatments, such as water washing and acid pickling, can reduce alkali content in biomass fuel and increase the fuel property to some extent. Largescale utilization of manual washing deserves to be investigated further. Co-firing of different types of biomass or coal can be used to relieve slagging on heating surface as well.

On basis of the research proceeding to date, more attention should be paid on the research of ashing temperature, evaluation criteria on AFC, the detailed mechanisms on the migration and transformation of alkali metals during combustion, the formation mechanisms on the alternating layered structure, slagging rate calculation, and the simulation of slagging formation and development, etc. Effect of season, soil type, and fertilizer on the biomass production, and chemical composition is also important research point.

\section{ACKNOWLEDGMENTS}

The present work was supported by the National Nature Science Foundation of China (51376147) and China Postdoctoral Science Foundation funded project (2013M532046).

\section{REFERENCES}

Aho, M. (2001). Reduction of chlorine deposition in FB boilers with aluminiumcontaining additives. Fuel 80, 1943-1951. doi:10.1016/S0016-2361(01)00049-7

Aho, M., and Ferrer, E. (2005). Importance of coal ash composition in protecting the boiler against chlorine deposition during combustion of chlorine-rich biomass. Fuel 84, 201-212. doi:10.1016/j.fuel.2004.08.022

Ai, J., Qin, Y., Zhu, Q., and He, P. (1994). Investigation on coal ash slagging index between China and overseas (Chinese). Power Syst. Eng. 10, 1-18.

Arias, B., Pevida, C., Fermoso, J., Plaza, M., Rubiera, F., and Pis, J. (2008). Influence of torrefaction on the grindability and reactivity of woody biomass. Fuel Process. Technol. 89, 169-175. doi:10.1016/j.fuproc.2007.09.002

Arvelakis, S., and Frandsen, F. J. (2007). Melting behavior of ashes from the co-combustion of coal and straw. Energy Fuels 21, 3004-3009. doi:10.1021/ ef070045m

Bartolomé, C., Gil, A., and Ramos, I. (2010). Ash deposition behavior of cynara-coal blends in a PF pilot furnace. Fuel Process. Technol. 91, 1576-1584. doi:10.1016/j. fuproc.2010.06.005

Broström, M., Kassman, H., Helgesson, A., Berg, M., Andersson, C., Backman, R., et al. (2007). Sulfation of corrosive alkali chlorides by ammonium sulfate in a biomass fired CFB boiler. Fuel Process. Technol. 88, 1171-1177. doi:10.1016/j.fuproc.2007.06.023

Carrillo, M., Staggenborg, S., and Pineda, J. (2014). Washing sorghum biomass with water to improve its quality for combustion. Fuel 116, 427-431. doi:10.1016/j.fuel.2013.08.028

Chen, W., and Jiang, N. (1995). A calculation of coal ash fusion temperature in China using coal composition (Chinese). Coal Process. Compr. Util. 1, 13-17. 
Chen, L. (2012). Discussion on the biomass power generation in China. Hydropower and New Energy, 3, 1-6. (In Chinese).

Cook, J., and Beyea, J. (2000). Bioenergy in the United States: progress and possibilities. Biomass Bioenergy 18, 441-455. doi:10.1016/S0961-9534(00)00011-8

Cui, H., Qiu, D., and Ren, F. (2012). Problem and government responsibility and its implementing mode in promotion of straw power generation projects in China. Res. Agr. Modern. 69-73. (In Chinese).

Davidsson, K., Åmand, L.-E., Steenari, B.-M., Elled, A.-L., Eskilsson, D., and Leckner, B. (2008). Countermeasures against alkali-related problems during combustion of biomass in a circulating fluidized bed boiler. Chem. Eng. Sci. 63, 5314-5329. doi:10.1016/j.ces.2008.07.012

Davidsson, K., Steenari, B.-M., and Eskilsson, D. (2007). Kaolin addition during biomass combustion in a $35 \mathrm{MW}$ circulating fluidized-bed boiler. Energy Fuels 21, 1959-1966. doi:10.1021/ef070055n

Demirbas, A. (2004). Combustion characteristics of different biomass fuels. Prog. Energy Combust. Sci. 30, 219-230. doi:10.1016/j.pecs.2003.10.004

Deng, L., Zhang, T., Liu, Y., Liu, Y., and Che, D. (2010). Effects of washing on fuel properties and combustion characteristics of biomass. J. Eng. Thermophys. 31, 1239-1242. (In Chinese).

Dong, X., Li, R., Liu, Z., Zhou, X., and Yin, B. (2009). "Investigation on the ash characteristic during co-firing of coal and biomass," in Proceedings of the CSEE, 118-124. (In Chinese).

Elled, A. L., Davidsson, K. O., and Åmand, L. E. (2010). Sewage sludge as a deposit inhibitor when co-fired with high potassium fuels. Biomass Bioenergy 34, 1546-1554. doi:10.1016/j.biombioe.2010.05.003

Gao, Y., Xiao, J., and Shen, L. (2009). "Performance Investigation of biomass gasification-molten carbonate fuel cell combined cycle power generation system," in Proceedings of the CSEE, 112-118. (In Chinese).

Gilbe, C., Lindstrom, E., Backman, R., Samuelsson, R., Burvall, J., and Ohman, M. (2008). Predicting slagging tendencies for biomass pellets fired in residential appliances: a comparison of different prediction methods. Energy Fuels 22, 3680-3686. doi:10.1021/ef800321h

Heinzel, T., Siegle, V., Spliethoff, H., and Hein, K. R. G. (1998). Investigation of slagging in pulverized fuel co-combustion of biomass and coal at a pilot-scale test facility. Fuel Process. Technol. 54, 109-125. doi:10.1016/S0378-3820(97)00063-5

Jensen, P. A., Stenholm, M., and Hald, P. (1997). Deposition investigation in strawfired boilers. Energy Fuels 11, 1048-1055. doi:10.1021/es202793c

Jiang, J. (2007). Conversion technology and utilization of biomass energy. Biomass Chem. Eng. 41, 59-65. (In Chinese).

Jiang, J., Ying, H., Jiang, J., and Tu, J. (2012). State of the art in biomass catalytic gasification. Biomass Chem. Eng. 46, 52-57. (In Chinese).

Johansson, L. S., Leckner, B., Tullin, C., Åmand, L.-E., and Davidsson, K. (2008). Properties of particles in the fly ash of a biofuel-fired circulating fluidized bed (CFB) boiler. Energy Fuels 22, 3005-3015. doi:10.1021/ef800266c

Kassman, H., Broström, M., Berg, M., and Åmand, L.-E. (2011). Measures to reduce chlorine in deposits: application in a large-scale circulating fluidised bed boiler firing biomass. Fuel 90, 1325-1334. doi:10.1016/j.fuel.2010.12.005

Khan, A. A., Aho, M., de Jong, W., Vainikka, P., Jansens, P. J., and Spliethoff, H. (2008). Scale-up study on combustibility and emission formation with two biomass fuels (B quality wood and pepper plant residue) under BFB conditions. Biomass Bioenergy 32, 1311-1321. doi:10.1016/j.biombioe.2008.03.011

Knudsen, J. N., Jensen, P. A., and Dam-Johansen, K. (2004). Transformation and release to the gas phase of $\mathrm{Cl}, \mathrm{K}$, and $\mathrm{S}$ during combustion of annual biomass. Energy Fuels 18, 1385-1399. doi:10.1021/ef049944q

Li, Q., She, Q., He, F., and Ren, J. (2009). Analysis on the influence of straw burning characteristic on boiler slag in straw-fired power plant. J. Shanghai Univ. Electr. Power 25, 441-444. (In Chinese).

Li, Q. H., Zhang, Y. G., Meng, A. H., Li, L., and Li, G. X. (2013). Study on ash fusion temperature using original and simulated biomass ashes. Fuel Process. Technol. 107, 107-112. doi:10.1016/j.fuproc.2012.08.012

Li, T., Li, A., Wan, L., and Zhang, C. (2012). Development status and analysis of microalgal bio-fuel patents in China. Renew. Energy Res. 30, 36-42. (In Chinese).

Liu, Y., Niu, Y., Tan, H., Liu, H., and Liu, Z. (2011). "Mechanism of deterioration of the deposits on secondary super-heater in biomass-fired boiler," in Proceedings of the CSEE, 8-12. (In Chinese).

Llorente, M. J. F., and Garcia, J. E. C. (2005). Comparing methods for predicting the sintering of biomass ash in combustion. Fuel 84, 1893-1900. doi:10.1016/j.fuel.2005.04.010
Ma, X., Ren T., Kong D., Nie, Y., Pang, M., and Xu, J., et al. (2011). “Experiments on mechanism of biomass ash slagging," in Electric Information and Control Engineering (ICEICE), Wuhan.

Mao, J., Xu, M., and Li, F. (2003). The effect of alkali mineral matter on the ash melting characteristic. J. Huazhong Univ. Sci. Technol. Med. Sci. 31, 59-62. (In Chinese).

Masia, A. A. T., Buhre, B. J. P., Gupta, R. P., and Wall, T. F. (2007). Characterising ash of biomass and waste. Fuel Process. Technol. 88, 1071-1081. doi:10.1016/j.fuproc.2007.06.011

Niu, Y., Liu, Y., Tan, H., Xiong, Y., and Xu, T. (2012). Origination and formation of $\mathrm{NH}_{4} \mathrm{Cl}$ in biomass-fired furnace. Fuel Process. Technol. 106, 262-266. doi:10.1016/j.fuproc.2012.08.006

Niu, Y., Tan, H., Wang, X., Liu, Z., Liu, Y., and Xu, T. (2010a). Study on deposits on the surface, upstream, and downstream of bag filters in a $12 \mathrm{MW}$ biomass-fired boiler. Energy Fuels 24, 2127-2132. doi:10.1021/ef901491a

Niu, Y., Tan, H., Wang, X., Liu, Z., Liu, H., Liu, Y., et al. (2010b). Study on fusion characteristics of biomass ash. Bioresour. Technol. 101, 9373-9381. doi:10.1016/ j.biortech.2010.06.144

Niu, Y. Q., Tan, H. Z., Ma, L., Pourkashanian, M., Liu, Z. N., Liu, Y., et al. (2010c). Slagging characteristics on the superheaters of a 12 MW biomass-fired boiler. Energy Fuels 24, 5222-5227. doi:10.1021/ef1013924

Niu, Y. Q., Tan, H. Z., Wang, X. B., Xu, T. M., Liu, Z. N., and Liu, Y. (2011). Fusion characteristics of capsicum stalk ash. Asia Pac. J. Chem. Eng. 6, 679-684. doi:10.1002/apj.452

Pettersson, A., Amand, L. E., and Steenari, B. M. (2009). Chemical fractionation for the characterisation of fly ashes from co-combustion of biofuels using different methods for alkali reduction. Fuel 88, 1758-1772. doi:10.1016/j.fuel.2009.03.038

Pettersson, A., Zevenhoven, M., Steenari, B.-M., and Åmand, L.-E. (2008). Application of chemical fractionation methods for characterisation of biofuels, waste derived fuels and CFB co-combustion fly ashes. Fuel 87, 3183-3193. doi:10.1016/j.fuel.2008.05.030

Sheehan, J., Dunahay, T., Benemann, J., and Roessler, P. (1998). A Look Back at the US Department of Energy's Aquatic Species Program: Biodiesel from Algae. Golden: National Renewable Energy Laboratory.

Steenari, B. M., and Lindqvist, O. (1998). High-temperature reactions of straw ash and the anti-sintering additives kaolin and dolomite. Biomass Bioenergy 14, 67-76. doi:10.1016/S0961-9534(97)00035-4

Steininger, K. W., and Voraberger, H. (2003). Exploiting the medium term biomass energy potentials in Austria: a comparison of costs and macroeconomic impact. Environ. Resource. Econ. 24, 359-377. doi:10.1023/A:1023680125027

Sun, Y., Yuan, Z., and Sun, Z. (2006). The status and future of bioenergy and biomass utilization in China. Renew. Energy 2, 78-82. (In Chinese).

Tang, J. (2013). Experimental Study on Ash Fusion Characteristics of Straw Biomass. Changchun: Jilin University.

Thy, P., Jenkins, B. M., Grundvig, S., Shiraki, R., and Lesher, C. E. (2009). High temperature elemental losses and mineralogical changes in common biomass ashes. Fuel 88, 1151-1151. doi:10.1016/j.fuel.2009.02.001

Turn, S. Q., Kinoshita, C. M., and Ishimura, D. M. (1997). Removal of inorganic constituents of biomass feedstocks by mechanical dewatering and leaching. Biomass Bioenergy 12, 241-252. doi:10.1016/S0961-9534(97)00005-6

Vainio, E., Yrjas, P., Zevenhoven, M., Brink, A., Laurén, T., and Hupa, M. (2013). The fate of chlorine, sulfur, and potassium during co-combustion of bark, sludge, and solid recovered fuel in an industrial scale BFB boiler. Fuel Process. Technol. 105, 59-68. doi:10.1016/j.fuproc.2011.08.021

Vamvuka, D. (2009). Comparative fixed/fluidized bed experiments for the thermal behaviour and environmental impact of olive kernel ash. Renew. Energy 34, 158-164. doi:10.1016/j.renene.2008.04.032

Vamvuka, D., Zografos, D., and Alevizos, G. (2008). Control methods for mitigating biomass ash-related problems in fluidized beds. Bioresour. Technol. 99, 3534-3544. doi:10.1016/j.biortech.2007.07.049

Wang, J., Hu, Z., Peng, B., Wang, H., and Cao, S. (2010a). General situation of biomass gasification technology in China. J. Agr. Mech. Res. 1, 198-201. (In Chinese).

Wang, X., Si, J., Tan, H., Ma, L., Pourkashanian, M., and Xu, T. (2010b). Nitrogen, sulfur, and chlorine transformations during the pyrolysis of straw. Energy Fuels 24, 5215-5221. doi:10.1021/ef1007215

Wang, S., Jiang, X., Wang, N., Yu, L., Li, Z., and He, P. (2008a). "Fusing characteristic analysis on seaweed biomass ash," in Proceedings of the CSEE, 96-101. (In Chinese) 
Wang, X., Chen, H., Wang, J., Xin, F., and Yang, H. (2008b). Influences of mineral matters on biomass pyrolysis characteristics. J. Fuel Chem. Technol. 36, 679-683. (In Chinese).

Wei, X., Schnell, U., and Hein, K. R. G. (2005). Behaviour of gaseous chlorine and alkali metals during biomass thermal utilisation. Fuel 84, 841-848. doi:10.1016/j.fuel.2004.11.022

Werkelin, J., Lindberg, D., Boström, D., Skrifvars, B.-J., and Hupa, M. (2011). Ashforming elements in four Scandinavian wood species part 3: combustion of five spruce samples. Biomass Bioenergy 35, 725-733. doi:10.1016/j.biombioe.2010. 10.010

Werkelin, J., Skrifvars, B.-J., Zevenhoven, M., Holmbom, B., and Hupa, M. (2010). Chemical forms of ash-forming elements in woody biomass fuels. Fuel 89, 481-493. doi:10.1016/j.fuel.2009.09.005

Wiesenthal, T., Mourelatou A., Petersen J., and Taylor P. (2006). How much Bioenergy can Europe Produce Without Harming the Environment? EEA Report, No. 7/2006. European Environment Agency, Office for Official Publications of the European Communities.

Wilen, C., Ståhlberg, P., Sipilä, K., and Ahokas, J. (1987). Pelletization and Combustion of Straw: Energy from Biomass and Wastes X. Washington, DC: IGT, 7-10.

Williams, A., Jones, J. M., Ma, L., and Pourkashanian, M. (2012). Pollutants from the combustion of solid biomass fuels. Prog. Energy Combust. Sci. 38, 113-137. doi:10.1016/j.pecs.2011.10.001

Wu, C., Yin, X., and Liu, H. (2013). Status and prospects for biomass gasification. J. Fuel Chem. Technol. 41, 798-804. (In Chinese).

Xiao, J., Duan, J., Wang, H., and Zhuang, X. (2003). The present situation of using biomass. Saf. Environ. Eng. 10, 11-14. (In Chinese).

Xiong, S., Burvall, J., Örberg, H., Kalen, G., Thyrel, M., Öhman, M., et al. (2008). Slagging characteristics during combustion of corn stovers with and without kaolin and calcite. Energy Fuels 22, 3465-3470. doi:10.1021/ef700718j
Xu, W., Niu, Y., Tan, H., Wang, D., Du, W., and Hui, S. (2013). A new agro/forestry residues co-firing model in a large pulverized coal furnace: technical and economic assessments. Energies 6, 4377-4393. doi:10.3390/en6094377

Yan, W., and Chen, Y. (2007). "Interaction performance of co-pyrolysis of biomass mixture and coal of different rank," in Proceedings of the CSEE, 80-86. (In Chinese).

Yang, Z., Jiang, J., Xu, J., and Hu, Y. (2013). Research progress on pressure liquefaction of biomass to bio-oil. Biomass Chem. Eng. 17, 29-34. (In Chinese).

Conflict of Interest Statement: The authors declare that the research was conducted in the absence of any commercial or financial relationships that could be construed as a potential conflict of interest.

Received: 02 December 2013; accepted: 10 February 2014; published online: 25 February 2014.

Citation: Zhu Y, Niu Y, Tan H and Wang X (2014) Short review on the origin and countermeasure of biomass slagging in grate furnace. Front. Energy Res. 2:7. doi: 10.3389/fenrg.2014.00007

This article was submitted to Bioenergy and Biofuel, a section of the journal Frontiers in Energy Research.

Copyright (c) $2014 \mathrm{Zhu}$, Niu, Tan and Wang. This is an open-access article distributed under the terms of the Creative Commons Attribution License (CC BY).

The use, distribution or reproduction in other forums is permitted, provided the original author(s) or licensor are credited and that the original publication in this journal is cited, in accordance with accepted academic practice. No use, distribution or reproduction is permitted which does not comply with these terms. 